\title{
Muscarinic Inhibition of Calcium Current and M Current in $\mathrm{G}_{\mathbf{q}^{-}}{ }^{-}$ Deficient Mice
}

\author{
Jane E. Haley, ${ }^{1}$ Patrick Delmas, ${ }^{1}$ Stefan Offermanns, ${ }^{2}$ Fe C. Abogadie, ${ }^{1}$ Melvin I. Simon, ${ }^{2}$ Noel J. Buckley, ${ }^{1}$ \\ and David A. Brown 1 \\ ${ }^{1}$ Wellcome Laboratory for Molecular Pharmacology, Department of Pharmacology, University College London, London, \\ WC1E 6BT, United Kingdom, and 2Division of Biology, California Institute of Technology, Pasadena, California 91125
}

Activation of $M_{1}$ muscarinic acetylcholine receptors $\left(M_{1}\right.$ mAChR) inhibits M-type potassium currents $\left(I_{\mathrm{K}(\mathrm{M})}\right)$ and N-type calcium currents $\left(I_{\mathrm{Ca}}\right)$ in mammalian sympathetic ganglia. Previous antisense experiments suggested that, in rat superior cervical ganglion (SCG) neurons, both effects were partly mediated by the G-protein $\mathrm{G} \alpha_{\mathrm{q}}$ (Delmas et al., 1998a; Haley et al., 1998a), but did not eliminate a contribution by other pertussis toxin (PTX)-insensitive G-proteins. We have tested this further using mice deficient in the $\mathrm{G} \alpha_{\mathrm{q}}$ gene.

PTX-insensitive $M_{1} m A C h R$ inhibition of $I_{\mathrm{Ca}}$ was strongly reduced in $\mathrm{G} \alpha_{\mathrm{q}}-/-$ mouse SCG neurons and was fully restored by acute overexpression of $\mathrm{G} \alpha_{\mathrm{q}}$. In contrast, $\mathrm{M}_{1} \mathrm{mAChR}$ inhibition of $I_{\mathrm{K}(\mathrm{M})}$ persisted in $\mathrm{G} \alpha_{\mathrm{q}}-/-$ mouse SCG cells. However, unlike rat SCG neurons, muscarinic inhibition of $I_{\mathrm{K}(\mathrm{M})}$ was partly PTX-sensitive. Residual (PTX-insensitive) $I_{\mathrm{K}(\mathrm{M})}$ inhibition was slightly reduced in $\mathrm{G} \alpha_{\mathrm{q}}-/-$ neurons, and the remaining response was then suppressed by anti- $\mathrm{G} \alpha_{\mathrm{q} / 11}$ antibodies.

Bradykinin (BK) also inhibits $I_{\mathrm{K}(\mathrm{M})}$ in rat SCG neurons via a PTX-insensitive G-protein $\left(\mathrm{G}_{\mathrm{q}}\right.$ and/or $\mathrm{G}_{11}$; Jones et al., 1995). In mouse SCG neurons, $I_{\mathrm{K}(\mathrm{M})}$ inhibition by BK was fully PTXresistant. It was unchanged in $\mathrm{G} \alpha_{\mathrm{q}}-/-$ mice but was abolished by anti-G $\alpha_{\mathrm{q} / 11}$ antibody.

We conclude that, in mouse SCG neurons (1) $M_{1} m A C h R$ inhibition of $I_{\mathrm{Ca}}$ is mediated principally by $G_{\mathrm{q}}$, (2) $M_{1} m A C h R$ inhibition of $I_{\mathrm{K}(\mathrm{M})}$ is mediated partly by $\mathrm{G}_{\mathrm{q}}$, more substantially by $\mathrm{G}_{11}$, and partly by a PTX-sensitive G-protein(s), and (3) BK-induced inhibition of $I_{\mathrm{K}(\mathrm{M})}$ is mediated wholly by $\mathrm{G}_{11}$.

Key words: $M$ current; calcium current; G-protein; superior cervical ganglion neuron; knock-out mouse; muscarinic receptor; bradykinin receptor
The excitability of neurons is controlled by the convergent action of many different ion channels, including voltage-gated $\mathrm{K}^{+}$and $\mathrm{Ca}^{2+}$ channels and ligand gated ion channels. N-Type $\mathrm{Ca}^{2+}$ channels have complex effects on cell excitability. They permit $\mathrm{Ca}^{2+}$ influx at presynaptic terminals, triggering exocytosis, thereby contributing to excitability. However, they also act to limit cell excitability by providing the $\mathrm{Ca}^{2+}$ necessary to open $\mathrm{Ca}^{2+}$ activated $\mathrm{K}^{+}$channels, resulting in a prolonged afterhyperpolarization and action potential accommodation (Davies et al., 1996; Sah, 1996). The M-type potassium current $\left(I_{\mathrm{K}(\mathrm{M})}\right)$ also acts to dampen cell excitability; it increases upon depolarization, hyperpolarizing the cell and keeping it clamped around rest and thus limiting action potential firing (Brown, 1988; Wang and McKinnon, 1995). Both the N-type $\mathrm{Ca}^{2+}$ channel and $I_{\mathrm{K}(\mathrm{M})}$ can be inhibited by G-protein-coupled receptors, such as the muscarinic acetylcholine $\mathrm{M}_{1}$ receptor $\left(\mathrm{M}_{1} \mathrm{mAChR}\right)$ (Marrion et al., 1989;

\footnotetext{
Received Nov. 9, 1999; revised Feb. 28, 2000; accepted March 17, 2000.

This work was supported by the Wellcome Trust and the UK Medical Research Council. We thank Mariza Dayrell, Brenda Browning, and Misbah Malik-Hall for tissue culture expertise and Prof. Graeme Milligan (Molecular Pharmacology Group, Division of Biochemistry and Molecular Biology, Institute of Biomedical and Life Sciences, University of Glasgow, Glasgow, UK) for the gift of $\mathrm{G} \alpha_{\mathrm{o}}$ and $\mathrm{G} \alpha_{\mathrm{q} / 11}$ antisera.

Correspondence should be addressed to Prof. David Brown, Department of Pharmacology, University College London, Gower Street, London WC1E 6BT, UK. E-mail: d.a.brown@ucl.ac.uk.

Dr. Offermanns's present address: Institut für Pharmakologie, Freie Universität Berlin, Thielallee 69-73, 14195 Berlin, Germany.

Dr. Buckley's present address: School of Biochemistry and Molecular Biology, University of Leeds, Leeds LS2 9JT, UK.

Copyright (C) 2000 Society for Neuroscience $\quad 0270-6474 / 00 / 203973-07 \$ 15.00 / 0$
}

Bernheim et al., 1992), and coincident inhibition of both currents results in large increases in cell excitability and action potential discharge (Jones and Adams, 1987; Brown, 1988, 1999).

In rat superior cervical ganglion (SCG), inhibition of $I_{\mathrm{Ca}}$ and $I_{\mathrm{K}(\mathrm{M})}$ by agonists acting at the $\mathrm{M}_{1} \mathrm{mAChR}$ appears to use very similar transduction mechanisms, and it has been suggested that they may share a common pathway (Hille, 1994). The first step in this pathway is the activation of a G-protein that is insensitive to pertussis toxin (PTX) (Brown et al., 1989; Bernheim et al., 1992). Previous experiments using the injection of antibodies directed against the common $\mathrm{C}$ terminus of $\mathrm{G} \alpha_{\mathrm{q}}$ and $\mathrm{G} \alpha_{11}$ (Caulfield et al., 1994) and the expression of separate antisense constructs specific to $\mathrm{G} \alpha_{\mathrm{q}}$ or $\mathrm{G} \alpha_{11}$ (Delmas et al., 1998a; Haley et al., 1998a) suggested that the G-protein primarily involved is $\mathrm{G} \alpha_{\mathrm{q}}$. However, because suppression by either method was incomplete, the participation of other G-protein(s) could not be discounted.

Bradykinin (BK) also inhibits $I_{\mathrm{K}(\mathrm{M})}$ in rat SCG neurons through stimulation of $B_{2}$ BK receptors (Jones et al., 1995). This effect was strongly attenuated by anti-G $\alpha_{\mathrm{q} / 11}$ antibodies (Jones et al., 1995), but the specific G-protein involved has not been further identified. It may, in fact, differ from that required for mAChRinduced inhibition because BK-induced inhibition clearly involves the activation of phospholipase $\mathrm{C}$, whereas $\mathrm{M}_{1}$ mAChR-induced inhibition appears not to (Cruzblanca et al., 1998; Haley et al., 1998b).

In an attempt to further define the role of $\mathrm{G} \alpha_{\mathrm{q}}$ in transducing the effects of $M_{1} m A C h R$ and $B_{2} B K$ receptors, we have therefore investigated the inhibition of $I_{\mathrm{Ca}}$ and $I_{\mathrm{K}(\mathrm{M})}$ by agonists for these receptors in SCG neurons isolated from mice lacking $\mathrm{G} \alpha_{\mathrm{q}}$ (Offermanns et al., 1997a,b). 
Parts of this work have been published previously in abstract form (Haley et al., 1998c).

\section{MATERIALS AND METHODS}

$G \alpha_{\mathrm{q}}$-Deficient mice. Mice deficient in the $\mathrm{G} \alpha_{\mathrm{q}}$ gene $\left(\mathrm{G} \alpha_{\mathrm{q}}-/-\right)$ were generated by targeted disruption with a neomycin gene as described previously (Offermanns et al., 1997a). G $\alpha_{\mathrm{q}}$-Deficient mice used in the experiments were obtained by mating either $\mathrm{G} \alpha_{\mathrm{q}}$ knock-out males with heterozygous females or heterozygous males and females (to obtain wild-type and knock-out littermates). Mice were kept on a C57BL $\times$ 129/Sv background, and genotypes were confirmed by PCR on genomic DNA from tail snips of each mouse.

Cell culture. Sympathetic neurons were isolated from $\mathrm{G} \alpha_{\mathrm{q}}$ knock-out and wild-type mice that were at least 5 weeks old. Wild-type mice were either C57BL/6J (Harlan, Bicester, UK) or from litters also containing $\mathrm{G} \alpha_{\mathrm{q}}$ knock-out littermates; results obtained were the same from both these groups and so have been pooled. We also used ICR mouse (coding for outbred albino mouse; Harlan) to compare properties of SCG neurons derived from different strain of mouse. SCG were removed, and neurons were cultured using standard procedures as described previously for rat (Delmas et al., 1998b).

Microinjection. In a few experiments, $\mathrm{G} \alpha_{\mathrm{oA}+\mathrm{B}}$ or $\mathrm{G} \alpha_{\mathrm{q} / 11}$ antiserum (OC2 and CQ1 respectively, from G. Milligan) (Caulfield et al., 1994, Delmas et al., 1998a, 1999) or an expression plasmid encoding $\mathrm{G} \alpha_{\mathrm{q}}$ were pressure-injected into the cytoplasm (antisera) or nucleus (plasmid) of SCG neurons $2 \mathrm{~d}$ in culture using a microinjector (Eppendorf, Hamburg, Germany). To allow identification of the injected neurons for recording, FITC-dextran (70,000 MW; Molecular Probes, Leiden, The Netherlands) was added in a final concentration of $0.2 \%$ (antisera) (Jones et al., 1995 ) or $0.5 \%$ (plasmid) (Haley et al., 1998a). Cells injected with the antisera were recorded at least $2 \mathrm{hr}$ after injection, whereas those injected with the $\mathrm{G} \alpha_{\mathrm{g}}$-encoding plasmid were recorded $24 \mathrm{hr}$ later.

Electrophysiology. Currents were measured from SCG neurons cultured for 2-3 d, using the amphotericin-B perforated patch technique (Horn and Marty, 1988; Rae et al., 1991). Patch electrodes (2-5 M $\Omega$ ) were filled by dipping the tip for $40 \mathrm{sec}$ into the appropriate filtered internal solution, and the pipette was then back-filled with the internal solution containing 0.07-0.1 $\mathrm{mg} / \mathrm{ml}$ amphotericin-B. High-resistance seals $(>2 \mathrm{G} \Omega$ ) were initially achieved and, after amphotericin-B permeabilization, access resistances were generally $<25 \mathrm{M} \Omega$ for $I_{\mathrm{K}(\mathrm{M})}$ recordings and $<15 \mathrm{M} \Omega$ for $I_{\mathrm{Ca}}$ recordings. SCG neurons were perfused (5-10 $\mathrm{ml} / \mathrm{min}$ ) with an external solution consisting of (in $\mathrm{mM}$ ): $\mathrm{NaCl} 120, \mathrm{KCl}$ 3, HEPES 5, $\mathrm{NaHCO}_{3}$ 23, glucose 11, $\mathrm{MgCl}_{2}$ 1.2, $\mathrm{CaCl}_{2}$ 2.5, and tetrodotoxin $0.0005, \mathrm{pH} 7.4$, maintained at $32^{\circ} \mathrm{C}$.

$\mathrm{I}_{K(M)}$ recording. The internal solution comprised of (in $\mathrm{mM}$ ): potassium acetate $80, \mathrm{KCl} 30, \mathrm{HEPES} 40$, and $\mathrm{MgCl}_{2} 3$, adjusted to $\mathrm{pH}$ 7.3-7.4 with $\mathrm{KOH}$ (280 $\mathrm{mOsm} / 1$ with $\mathrm{K}$ acetate). Cells were voltage-clamped using an Axoclamp-2A (switching frequencies 3-5 kHz, filter $0.1 \mathrm{kHz}$ ) from Axon Instruments (Foster City, CA). $I_{\mathrm{K}(\mathrm{M})}$ was measured as a slowly developing inward deactivation relaxation after a $1 \mathrm{sec}$ jump to a command potential of approximately $-45 \mathrm{mV}$ from a holding potential of approximately $-25 \mathrm{mV}$ (Haley et al., 1998a). Inhibition was measured as the fractional reduction in the amplitude of the $I_{\mathrm{K}(\mathrm{M})}$ deactivation relaxation in response to either cumulatively increasing concentrations of oxotremorine methiodide (Oxo-M) (Research Biochemicals, Natick, MA) or a single application of $1 \mathrm{~nm}$ BK (Bachem, Torrance, CA).

$\mathrm{I}_{\mathrm{Ca}}$ recording. Perforated patch recordings were conducted primarily as described previously (Delmas et al., 1999). Pipettes had a resistance of 2-3 $\mathrm{M} \Omega$ when filled with the following solution (in $\mathrm{mm}$ ): $\mathrm{CsCl} \mathrm{30,}$ caesium acetate 110 , HEPES 10 , and $\mathrm{MgCl}_{2}$ 1, pH 7.2-7.3 with $\mathrm{CsOH}$ (300 mOsm/1). Cells were voltage-clamped using an Axopatch 200A amplifier (Axon Instruments). Series resistance and membrane capacitance were partially compensated $(>80 \%)$. Current traces were low-pass filtered at $2-5 \mathrm{kHz}$ using a four-pole Bessel filter. Leak and capacitance currents were subtracted digitally using the $\mathrm{P} / 6$ subtraction procedure of pClamp6 (Axon Instruments). $I_{\mathrm{Ca}}$ was elicited from a holding potential of $-70 \mathrm{mV}$ with a three-voltage pulse protocol consisting of a test pulse to $0 \mathrm{mV}$ applied before and after a conditioning depolarizing step to $+90 \mathrm{mV}$.

For experiments with Bordetella PTX (Speywood, Maidenhead, Berkshire, UK), SCG neurons were incubated with $1 \mu \mathrm{g} / \mathrm{ml}$ PTX in the culture medium for at least $24 \mathrm{hr}$ before recording. Data are expressed as mean \pm SEM, and statistical analysis of dose-response curves used two-way ANOVA to compare treatments across all concentrations. If a significant effect of treatment was found overall, further analysis was

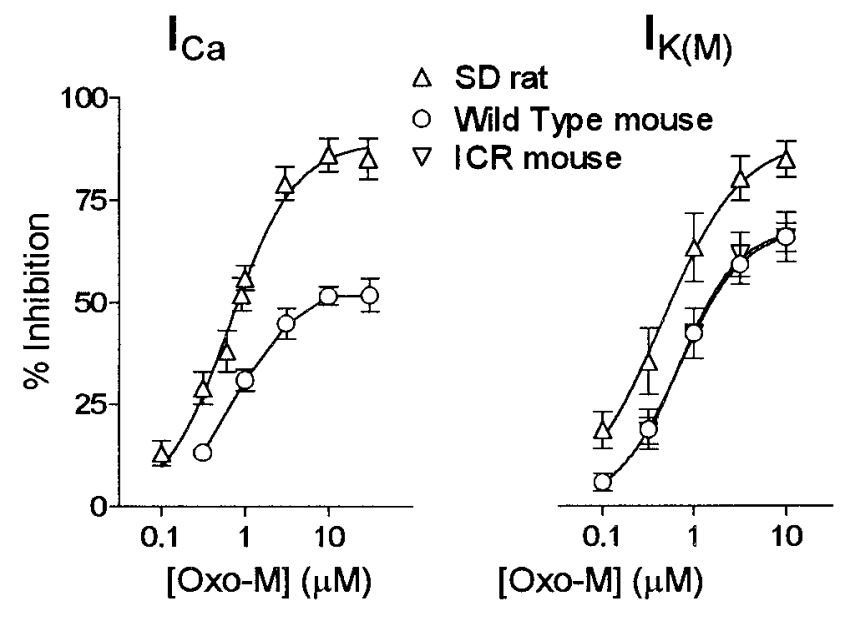

Figure 1. Dose-response curves (mean \pm SEM plus best-fit curve) for Oxo-M inhibition of $I_{\mathrm{Ca}}$ and $I_{\mathrm{K}(\mathrm{M})}$ in rat and mouse SCG. $I_{\mathrm{Ca}}$, Left, Oxo-M dose-response curves determined after treatment with PTX, thereby isolating the $\mathrm{M}_{1} \mathrm{mAChR}$-mediated component. $n$ values for each concentration point range from 3 to 7 . $I_{\mathrm{K}(\mathrm{M})}$, Right, Oxo-M dose-response curve in wild-type mouse SCG $(n=9)$ is significantly different from that seen in rat SCG $(n=4 ; p<0.001)$. The rat $I_{\mathrm{K}(\mathrm{M})}$ dose-response curve data are taken from Haley et al. (1998a), and the rat $I_{\mathrm{Ca}}$ dose-response curve data are from Delmas et al. (1998a). Legend applies to both panels. All cells were recorded using the perforated patch method.

performed using the two-way ANOVA to determine which treatment groups contributed to this significance. The bradykinin data were analyzed with one-way ANOVA, and if an overall effect of treatment was found, this was followed by Students-Newman-Keuls multiple comparison test. Analysis of $I_{\mathrm{Ca}}$ and $I_{\mathrm{K}(\mathrm{M})}$ current densities and neuron membrane potential was analyzed using Student's $t$ test. $p<0.05$ was considered significant.

Immunocytochemistry. Successf ul injection of $\mathrm{G} \alpha_{\mathrm{o}}$ or $\mathrm{G} \alpha_{\mathrm{q} / 11}$ antiserum was confirmed by staining. After recording, cells were fixed in acetone, washed, incubated with biotinylated Fab2 swine anti-rabbit antibody (the antiserum was raised in rabbit), and then incubated with avidin-biotin complex. The alkaline phosphatase substrate 5-bromo-4-chloro-3-indoxyl phosphate/nitro blue tetrazolium chloride (BCIP/NBT) (Dako, Carpinteria, CA) was applied for $5 \mathrm{~min}$, and the reaction was quenched with water. Neurons containing the injected antiserum were clearly distinguished as containing the dark purple BCIP/NBT product. Detection of expressed $\mathrm{G} \alpha_{\mathrm{q}}$ after injection of the $\mathrm{G} \alpha_{\mathrm{q}}$ plasmid was confirmed using the above protocol and preceding it with a $1 \mathrm{hr}$ incubation with a 1:2000 dilution of a $\mathrm{G} \alpha$ q antibody (IQB2) (Milligan et al., 1993).

\section{RESULTS}

\section{$\mathrm{M}_{1}$ mAChR-induced inhibition of $I_{\mathrm{Ca}}$ and $I_{\mathrm{K}(\mathrm{M})}$ in mouse versus rat SCG}

The mAChR agonist Oxo-M inhibited both $I_{\mathrm{Ca}}$ and $I_{\mathrm{K}(\mathrm{M})}$ (see also Hamilton et al., 1997) in SCG from mouse. However, the dose-response curves were shifted to the right in mouse compared with rat neurons (Fig. 1). $\mathrm{IC}_{50}$ values for $I_{\mathrm{K}(\mathrm{M})}$ inhibition were 0.4 and $0.7 \mu \mathrm{M}$ in rat and wild-type mouse, respectively. For $\mathrm{M}_{1} \mathrm{mAChR}$ inhibition of $I_{\mathrm{Ca}}, \mathrm{IC}_{50}$ were $800 \mathrm{nM}$ and $1.1 \mu \mathrm{M}$ in rat and mouse, respectively.

\section{$\mathrm{M}_{1}$ mAChR inhibition of $I_{\mathrm{Ca}}$ is reduced in $\mathrm{G}_{\mathrm{q}}-/-$ mouse SCG neurons}

In rat SCG, inhibition of $I_{\mathrm{Ca}}$ by $\mathrm{mAChR}$ agonists results from the activation of two separate pathways: a voltage- and PTX-sensitive $\mathrm{M}_{4} \mathrm{mAChR}$ pathway $\left(\mathrm{M}_{2}\right.$ receptors in mice) (Shapiro et al., 1999) that requires $\mathrm{G} \alpha_{\mathrm{oA}}$ and a voltage- and PTX-insensitive $\mathrm{M}_{1}$ mAChR pathway that mostly involves $\mathrm{G} \alpha_{\mathrm{q}}$ (Delmas et al., 1998a). In mice, total mAChR inhibition of $I_{\mathrm{Ca}}$ was significantly $(p<$ 0.002 ) reduced when $\mathrm{G} \alpha_{\mathrm{q}}$ was deleted. Thus, 1 and $10 \mu \mathrm{M}$ Oxo-M 
A
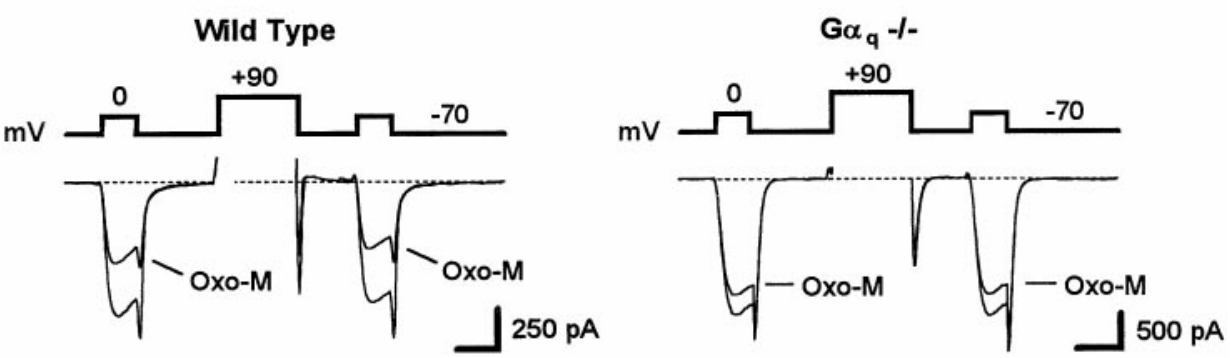

B

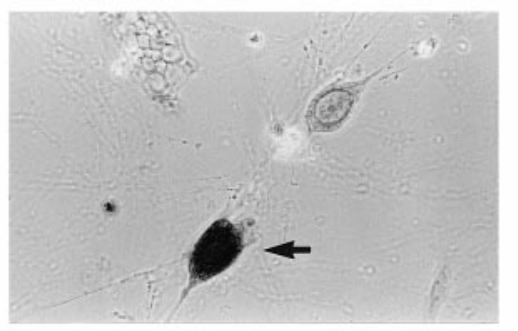

D

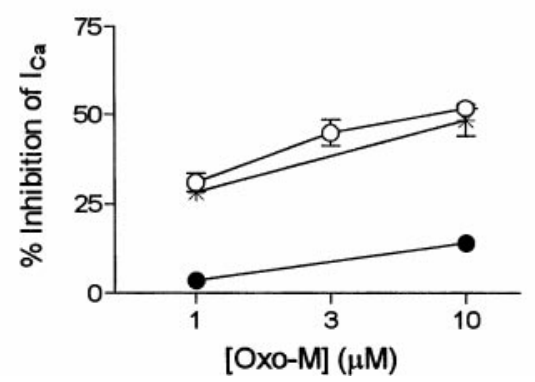

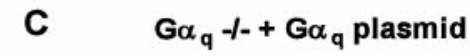
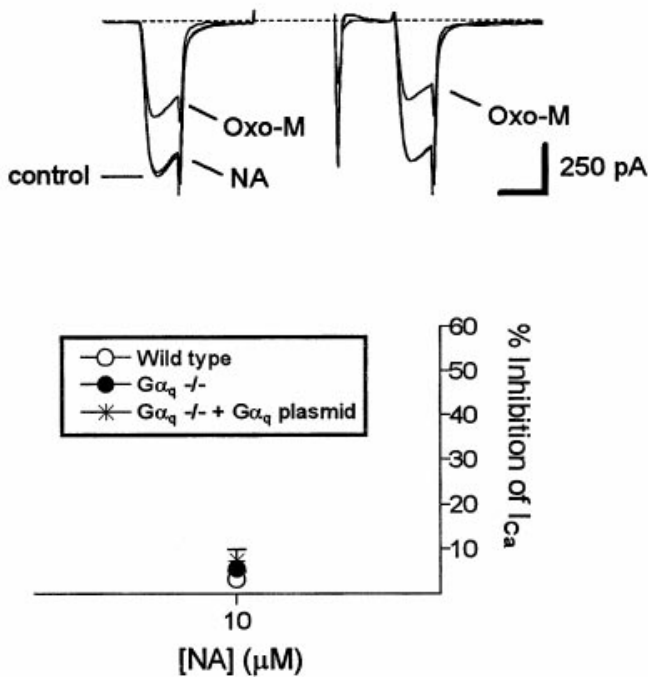

Figure 2. $\quad \mathrm{M}_{1} \mathrm{mAChR}$ inhibition of $I_{\mathrm{Ca}}$ is markedly reduced in $\mathrm{G} \alpha_{\mathrm{q}}-/-$ mice. All experiments were performed on neurons pretreated with PTX. $A, I_{\mathrm{Ca}}$ waveforms in SCG neurons from wildtype (left) and $\mathrm{G} \alpha_{\mathrm{q}}-/-$ mice (right) in the absence and presence of $10 \mu \mathrm{M}$ Oxo-M, using the three-step voltage protocol illustrated above each waveform. The conditioning step to $+90 \mathrm{mV}$ did not reverse Oxo-M inhibition in either wild-type or $\mathrm{G} \alpha_{\mathrm{q}}-/-$ neurons, confirming the voltage-independent nature of the PTX-insensitive inhibition. Calibration: 5 msec. $B, \mathrm{G} \alpha_{\mathrm{q}}$ is expressed in a $\mathrm{G} \alpha_{\mathrm{q}}-/-$ neuron after injection of a $\mathrm{G} \alpha_{\mathrm{q}}$ expression plasmid (injected cell indicated by arrow). $C$, In $\mathrm{G} \alpha_{\mathrm{q}}-/-$ neurons, Oxo-M inhibition of $I_{\mathrm{Ca}}$ is restored by exogenous expression of $\mathrm{G} \alpha_{\mathrm{q}} . D$, Summary of $\mathrm{M}_{1} \mathrm{mAChR}$ and noradrenergic inhibitions of $I_{\mathrm{Ca}}$. Note that NA inhibition cannot be restored in $\mathrm{G} \alpha_{\mathrm{q}}$ $-/-$ SCG neurons by expression of $\mathrm{G} \alpha_{\mathrm{q}}$. $n$ ranges from 6 to 10 for Oxo-M data and from 4 to 7 for NA data. resulted in $49 \pm 4 \%(n=8)$ and $68 \pm 4 \%(n=12)$ inhibition, respectively, in wild-type $\left(\mathrm{G} \alpha_{\mathrm{q}}+/+\right)$ mouse neurons and $29 \pm$ $3 \%(n=5)$ and $57 \pm 3 \%(n=5)$ inhibition in $\mathrm{G} \alpha_{\mathrm{q}}-/-$ neurons. Inhibition in $\mathrm{G} \alpha_{\mathrm{q}}-/-$ neurons was more voltage-dependent than in wild-type neurons, with facilitation ratio of $1.4 \pm 0.2(n=10)$ and $0.94 \pm 0.1(n=8)$, respectively (data not shown). Inhibition by $10 \mu \mathrm{M}$ noradrenaline (NA) (which requires both $\mathrm{G} \alpha_{\mathrm{oA}}$ and $\mathrm{G} \alpha_{\mathrm{i}}$ in rat) (Caulfield et al., 1994; Delmas et al., 1999) was not altered when $\mathrm{G} \alpha_{\mathrm{q}}$ was absent (wild type, $66 \pm 3 \%, n=8$; $\mathrm{G} \alpha_{\mathrm{q}}-/-, 62 \pm$ $5 \%, n=5)$.

Incubation with $1 \mu \mathrm{M}$ PTX inactivates members of the $\mathrm{G} \alpha_{\mathrm{o} / \mathrm{i}}$ G-protein family, removes the PTX-sensitive mAChR inhibition, and isolates the $\mathrm{M}_{1} \mathrm{mAChR}$ inhibition, as well as abolishes inhibition by NA (Schofield, 1991; Zhu and Ikeda, 1994). Inhibition by NA was, as expected, abolished in PTX-treated cells from both wild-type and $\mathrm{G} \alpha_{\mathrm{q}}-/-$ mice. After PTX treatment, it became clear that the reduction in $\mathrm{M}_{1}$ plus $\mathrm{M}_{2}$ inhibition observed in the $\mathrm{G} \alpha_{\mathrm{q}}-/-$ cells resulted from an almost complete loss of the voltage-insensitive $\mathrm{M}_{1} \mathrm{mAChR}$-mediated inhibition (Fig. 2). To be sure that the loss of $\mathrm{M}_{1} \mathrm{mAChR}$ inhibition of $I_{\mathrm{Ca}}$ was attributable to the absence of $\mathrm{G} \alpha_{\mathrm{q}}$, we acutely overexpressed $\mathrm{G} \alpha_{\mathrm{q}}$ in cultured SCG neurons from $\mathrm{G} \alpha_{\mathrm{q}}-/-$ mice. Twenty-four hours after injection of a plasmid encoding for $\mathrm{G} \alpha_{\mathrm{q}}, \mathrm{M}_{1} \mathrm{mAChR}$ inhibition was fully restored (Fig. $2 C$ ). This reinstated inhibition was specific because NA inhibition was not rescued by $\mathrm{G} \alpha_{\mathrm{q}}$ overexpression in PTX-treated cells (Fig. 2). These findings accord with previous data from this laboratory that $M_{1} m A C h R$ inhibition of $I_{\mathrm{Ca}}$ in rat SCG is primarily mediated by $\mathrm{G} \alpha_{\mathrm{q}}$ (Delmas et al., 1998a). It should be noted that the $I_{\mathrm{Ca}}$ density (normalized to cell capacitance) was significantly lower in $\mathrm{G} \alpha_{\mathrm{q}}-/-$ neurons $(27 \pm 2 \mathrm{pA} / \mathrm{pF}, n=10)$ compared with wild-type mouse SCG $(38 \pm 2 \mathrm{pA} / \mathrm{pF}, n=12, p<0.01)$. There was no difference between $I_{\mathrm{Ca}}$ density in wild-type mouse and rat SCG (rat, $42 \pm 2$ $\mathrm{pA} / \mathrm{pF}, n=19)$.

\section{$M_{1}$ mAChR inhibition of $I_{K(M)}$ is not reduced in SCG from $\mathbf{G} \alpha_{\mathbf{q}}-/-$ mouse}

In rat SCG, inhibition of $I_{\mathrm{K}(\mathrm{M})}$ by $\mathrm{mAChR}$ agonists is mediated, at least in part, by $\mathrm{G} \alpha_{\mathrm{q}}$ (Haley et al., 1998a), so one would predict a loss of inhibition in neurons lacking $\mathrm{G} \alpha_{\mathrm{q}}$. We were surprised, therefore, to discover that inhibition of $I_{\mathrm{K}(\mathrm{M})}$ by Oxo-M was not reduced in $\mathrm{G} \alpha_{\mathrm{q}}-/-\mathrm{SCG}$ compared with wild-type neurons (Fig. 3). Indeed, Oxo-M produced significantly more inhibition in $\mathrm{G} \alpha_{\mathrm{q}}$ $-/-$ neurons $(p<0.05)$, and the dose-response curve lay to the left of the wild-type dose-response (Fig. $3 B$ ). $I_{\mathrm{K}(\mathrm{M})}$ density (normalized to cell capacitance) was not changed in $\mathrm{G} \alpha_{\mathrm{q}}-/-$ mouse SCG compared with wild type, and neither was the resting membrane potential (wild type, $2.5 \pm 0.5 \mathrm{pA} / \mathrm{pF}, n=8 ;-58.0 \pm 1.3$ $\mathrm{mV}, n=9 ; \mathrm{G} \alpha_{\mathrm{q}}-/-, 3.3 \pm 1.1 \mathrm{pA} / \mathrm{pF}, n=9 ;-56.3 \pm 1.3 \mathrm{mV}$, $n=11)$, and these did not differ from rat SCG $(2.4 \pm 0.3 \mathrm{pA} / \mathrm{pF}$, $n=10 ;-59.9 \pm 1.3 \mathrm{mV})$.

\section{$M_{1}$ mAChR inhibition of $I_{K(M)}$ partly involves PTX- sensitive G-proteins in mouse SCG}

One factor contributing to the persistence of mAChR-induced inhibition of $I_{\mathrm{K}(\mathrm{M})}$ in neurons from $\mathrm{G} \alpha_{\mathrm{q}}$-deficient mice became apparent when we tested the effect of PTX. In contrast to previous observations on rat SCG neurons (Brown et al., 1989; Bernheim et al., 1992; Haley et al., 1998a), PTX treatment significantly reduced inhibition by Oxo-M in neurons from both wild-type 
A
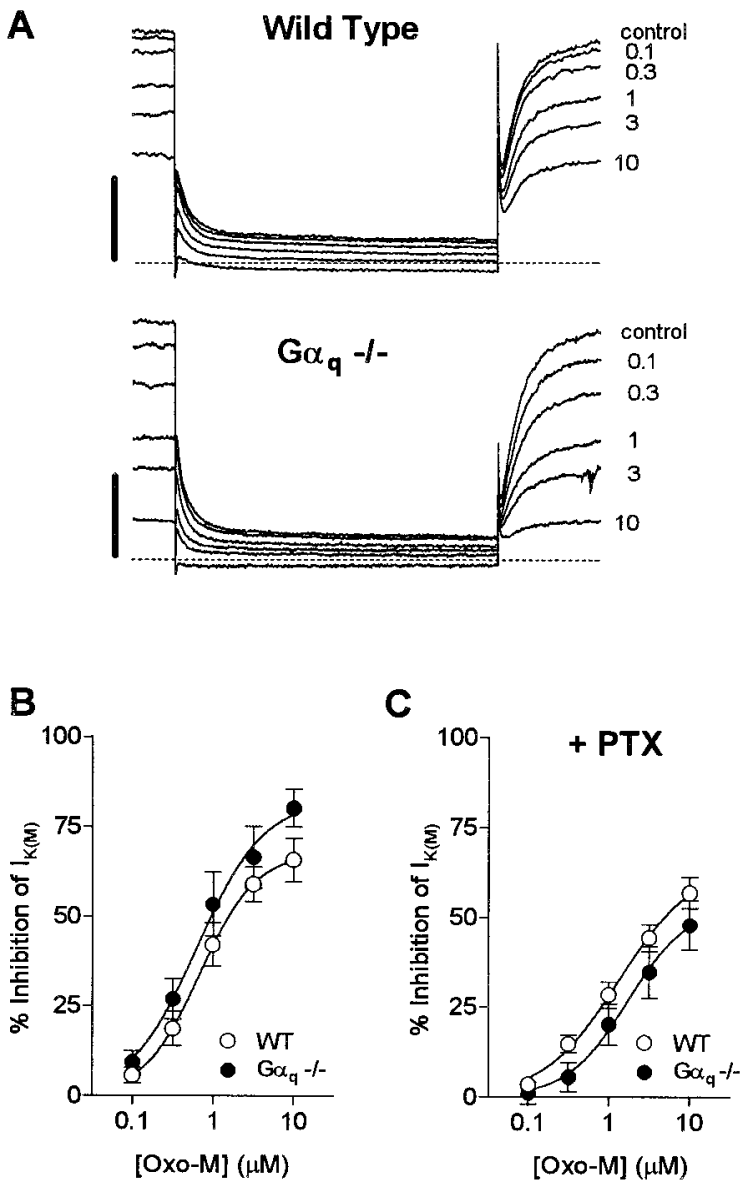

Figure 3. $\mathrm{M}_{1} \mathrm{mAChR}$ inhibition of $I_{\mathrm{K}(\mathrm{M})}$ is not reduced in $\mathrm{G} \alpha_{\mathrm{q}}-/-$ mice. $A, I_{\mathrm{K}(\mathrm{M})}$ deactivation relaxation elicited by a $-20 \mathrm{mV}$ step for $1 \mathrm{sec}$ from a holding potential of $-25 \mathrm{mV}$. Waveforms (average of 6 traces) are from SCG neurons of wild-type (top) and $\mathrm{G} \alpha_{\mathrm{q}}-/-$ (bottom) mice and are shown in the absence and presence of increasing concentrations of Oxo-M (micromolar). Dotted lines indicate 0 pA. Calibration: 250 pA. B, Mean \pm SEM data (plus best-fit curves) for Oxo-M inhibition of $I_{\mathrm{K}(\mathrm{M})}$ in wild-type and $\mathrm{G} \alpha_{\mathrm{q}}-/-\mathrm{SCG}$ neurons. Oxo-M dose-response curve in $\mathrm{G} \alpha_{\mathrm{q}}-1-$ neurons $(n=8)$ was significantly different from wild type $(n=9 ; p<$ 0.05). $\mathrm{IC}_{50}$ and Hill slope values for inhibition in $\mathrm{G} \alpha_{\mathrm{q}}-/-$ cells are $0.6 \mu \mathrm{M}$ and 1.1, respectively. $C$, Oxo-M dose-response curves in wild-type and $\mathrm{G} \alpha_{\mathrm{q}}-/-\mathrm{SCG}$ neurons treated with PTX. $\mathrm{IC}_{50}$ and Hill slope values were $1.3 \mu \mathrm{M}$ and 0.93 , and $1.7 \mu \mathrm{M}$ and 1.16 in wild-type and $\mathrm{G} \alpha_{\mathrm{q}}-/-$ cells, respectively.

mice $(p<0.01)$ and $\mathrm{G} \alpha_{\mathrm{q}}-/-$ mice $(p<0.0001)$ (Fig. 4). In fact, the effect of PTX was greater in $\mathrm{G} \alpha_{\mathrm{q}}$-deficient neurons, and the dose-response curve for the PTX-insensitive component of inhibition showed a significant $(p<0.02)$ rightward shift in $\mathrm{G} \alpha_{\mathrm{q}}-/-$ neurons. Thus, at $0.3 \mu \mathrm{M}$ Oxo-M, the mean inhibition of $I_{\mathrm{K}(\mathrm{M})}$ was reduced from $15 \pm 3$ to $6 \pm 4 \%$. Hence, it appeared that $\mathrm{G} \alpha_{\mathrm{q}}$ contributed a component of PTX-insensitive inhibition at low agonist concentrations but that, at high agonist concentrations, activation of another PTX-insensitive G-protein predominated.

One possibility is that this residual PTX-insensitive inhibition might have been mediated by $\mathrm{G}_{11}$, because expression of constitutively activated $\mathrm{G} \alpha_{11}$ is also capable of inhibiting $I_{\mathrm{K}(\mathrm{M})}$ in rat SCG neurons (Haley et al., 1998a). To test this, we injected antibodies directed against the $\mathrm{C}$ terminus of $\mathrm{G} \alpha_{\mathrm{q} / 11}$ into the cell cytosol of PTX-treated neurons, using antibodies against $\mathrm{G} \alpha_{\mathrm{o}}$ as a control (Caulfield et al., 1994). Anti-G $\alpha_{\mathrm{q} / 11}$ strongly reduced PTX-insensitive inhibition in neurons from wild-type mice and virtually annulled the residual inhibition in neurons from $\mathrm{G} \alpha_{\mathrm{q}}$ $-/-$ mice $(p<0.0001)$. Thus, the residual PTX-insensitive inhibition in neurons from $\mathrm{G} \alpha_{\mathrm{q}}-/-$ mice results from activation of $\mathrm{G} \alpha_{11}$ because the antibody is specific to $\mathrm{G} \alpha_{\mathrm{q}}$ and $\mathrm{G} \alpha_{11}$, and $\mathrm{G} \alpha_{\mathrm{q}}$ is absent.

\section{Inhibition of $I_{K(\mathrm{M})}$ by $\mathrm{BK}$ is mediated by $\mathrm{G} \alpha_{11}$ in $\mathbf{G} \alpha_{\mathrm{q}}-/-$ neurons}

For these experiments, a single application of a low concentration (1 nM) of BK was made to each neuron tested because slow recovery from inhibition precluded repeated applications to the same neuron and desensitization precluded applications of incremental concentrations (Jones et al., 1995; Cruzblanca et al., 1998). At $1 \mathrm{~nm}, \mathrm{BK}$ inhibited $I_{\mathrm{K}(\mathrm{M})}$ in wild-type mouse SCG neurons by $25 \pm 4 \%(n=8)$. This was not significantly different from that in rat SCG neurons $(29 \pm 7 \% ; n=8$; data not shown). Unlike mAChR-induced inhibition, the effect of BK on mouse neurons was not reduced by PTX (Fig. 5). This accords with previous observations on rat neurons (Jones et al., 1995). No inhibition of $I_{\mathrm{Ca}}$ by $1 \mathrm{~nm}$ BK could be detected.

No significant reduction of BK-induced inhibition of $I_{\mathrm{K}(\mathrm{M})}$ was observed in $\mathrm{G} \alpha_{\mathrm{q}}-/-$ neurons. However, injection of an antibody against $\mathrm{G} \alpha_{\mathrm{q} / 11}$ substantially ( $p<0.05$ vs anti- $\mathrm{G}_{\mathrm{o}}$ antibody) reduced $I_{\mathrm{K}(\mathrm{M})}$ inhibition in wild-type mouse neurons (as in rat neurons; Jones et al., 1995) and abolished inhibition in neurons from $\mathrm{G} \alpha_{\mathrm{q}}-/-$ mice $(p<0.01)$ (Fig. $\left.5 B\right)$.

\section{DISCUSSION}

Using mice lacking $\mathrm{G} \alpha_{\mathrm{q}}$, we have demonstrated that $\mathrm{M}_{1} \mathrm{mAChR}$ inhibition of $I_{\mathrm{Ca}}$ requires $\mathrm{G} \alpha_{\mathrm{q}}$ because regulation was essentially lost in $\mathrm{G} \alpha_{\mathrm{q}}-/-$ neurons (Fig. 2). This was not a result of secondary effects on transduction mechanisms arising from an absence of $\mathrm{G} \alpha_{\mathrm{q}}$ during development because inhibition could be fully restored by acute overexpression of $\mathrm{G} \alpha_{\mathrm{q}}$ in $\mathrm{G} \alpha_{\mathrm{q}}-/-$ neurons (Fig. 2); thus, the remaining components of the inhibitory pathway were still present and functional in these mutant cells. In contrast, neither the inhibition produced by NA nor the PTXsensitive $\left(\mathrm{M}_{2}\right)$ component of $\mathrm{mAChR}$ inhibition (Shapiro et al., 1999) were reduced after deletion of the $\mathrm{G} \alpha_{\mathrm{q}}$ genes. Hence, these results in mouse neurons are in complete accord with previous conclusions from observations on rat SCG neurons using G-protein antibody injections and antisense depletion (Caulfield et al., 1994; Delmas et al., 1998a) that $\mathrm{G} \alpha_{\mathrm{q}}$ is the primary G-protein involved in $\mathrm{M}_{1} \mathrm{mAChR}$-induced inhibition of $I_{\mathrm{Ca}}$ but is not involved in the inhibition produced by activating $\mathrm{M}_{2 / 4}$ mAChRs or $\alpha_{2}$ adrenergic receptors. It is especially worth noting (particularly in connection with our observations on $I_{\mathrm{K}(\mathrm{M})}$; see below) that $\mathrm{G} \alpha_{11}$ appears not to be able to substitute for $\mathrm{G} \alpha_{\mathrm{q}}$ in $\mathrm{G} \alpha_{\mathrm{q}}-/-$ mice, although it is able to interact with $\mathrm{M}_{1} \mathrm{mAChRs}$ (Offermanns et al., 1994; Gudermann et al., 1996) and although expression of a constitutively active form of $\mathrm{G} \alpha_{11}$ can inhibit $I_{\mathrm{Ca}}$ just like $\mathrm{G} \alpha_{\mathrm{q}}$ (unpublished observations; Delmas et al., 1998a).

In contrast [and surprisingly, in view of previous observations in rat SCG neurons using $\mathrm{G} \alpha_{\mathrm{q}}$ antisense (Haley et al., 1998a)], mAChR-induced inhibition of $I_{\mathrm{K}(\mathrm{M})}$ was not reduced in neurons from $\mathrm{G} \alpha_{\mathrm{q}}-/-$ mice. One contributory reason for this seemed to be that $I_{\mathrm{K}(\mathrm{M})}$ inhibition after mAChR stimulation was partly sensitive to PTX. When this component was eliminated, it appeared that some part of the inhibition (particularly at low agonist concentrations) was mediated by $\mathrm{G} \alpha_{\mathrm{q}}$ because the dose-response curve for Oxo-M-induced $\mathrm{M}$ current inhibition was shifted significantly to the right in $\mathrm{G} \alpha_{\mathrm{q}}-/-$ mice. Nevertheless, it was clear 
A
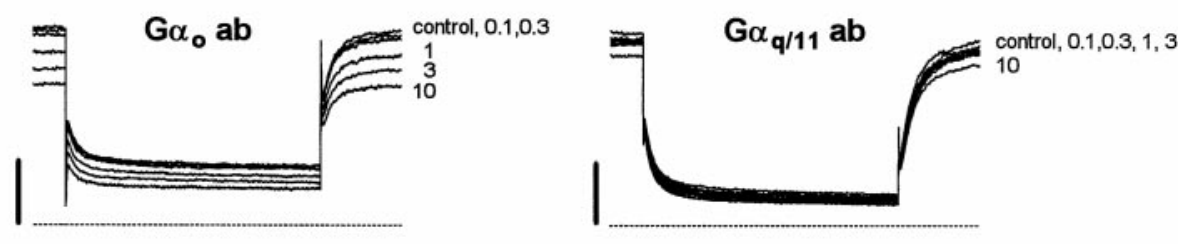

B

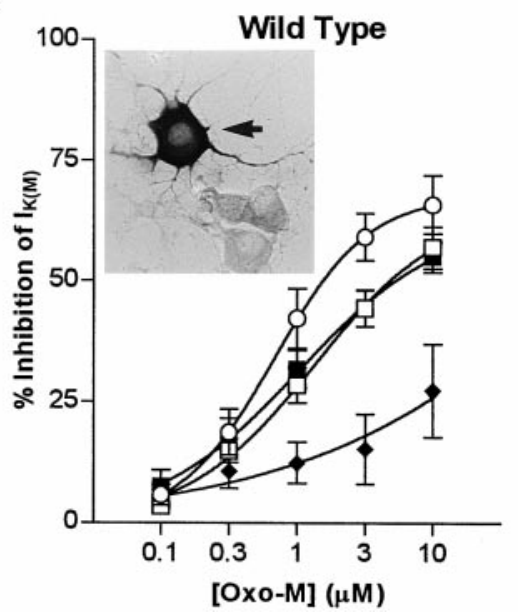

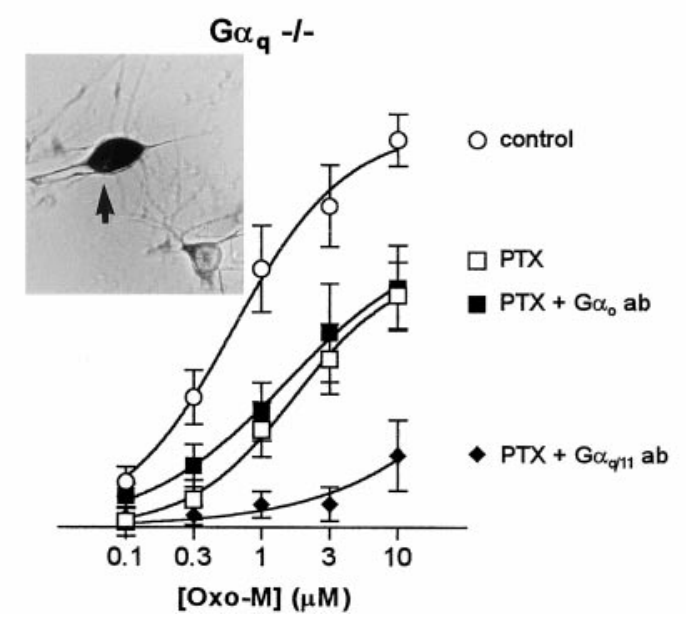

Figure 4. PTX-sensitive G-proteins and $\mathrm{G} \alpha_{11}$ mediate Oxo-M inhibition of $I_{\mathrm{K}(\mathrm{M})}$ in $\mathrm{G} \alpha_{\mathrm{q}}-/-$ neurons. $A$, Representative waveforms ( $1 \mathrm{sec}$ step from -25 to $-45 \mathrm{mV}$ ) recorded from $\mathrm{G} \alpha_{\mathrm{q}}-/-$ neurons treated with PTX and injected with either $\mathrm{G} \alpha_{\mathrm{oA}+\mathrm{B}}$ antibody or $\mathrm{G} \alpha_{\mathrm{q} / 11}$ antibody. Whereas cumulative concentrations of Oxo-M (micromolar) still produce inhibition in the $\mathrm{G} \alpha_{\mathrm{OA}+\mathrm{B}}$ antibodyinjected cell, there was very little inhibition in presence of the $\mathrm{G} \alpha_{\mathrm{q} / 11}$ antibody. Dotted lines indicate $0 \mathrm{pA}$. Calibration: $250 \mathrm{pA}$. $B$, Mean \pm SEM data (plus best-fit curves) for Oxo-M inhibition of $I_{\mathrm{K}(\mathrm{M})}$ in wild-type and $\mathrm{G} \alpha_{\mathrm{q}}-/-$ neurons. PTX treatment significantly reduced Oxo-M inhibition in both wildtype $(n=8 ; p<0.01)$ and $\mathrm{G} \alpha_{\mathrm{q}}-/-$ neurons $(n=10 ; p<0.0001)$. Injection of a $\mathrm{G} \alpha_{\mathrm{oA}+\mathrm{B}}$ antibody had no effect on PTX-treated cells from either wild-type $(n=7)$ or $\mathrm{G} \alpha_{\mathrm{q}}-/-(n=7)$ mice and served as an injection control. Injection of a $\mathrm{G} \alpha_{\mathrm{q} / 11}$ antibody reduced the remaining PTX-insensitive inhibition in both the wild-type $(n=4 ; p<0.0001$ compared with $\mathrm{G} \alpha_{\mathrm{OA}+\mathrm{B}}$ antibodyinjected cells) and $\mathrm{G} \alpha_{\mathrm{q}}-/-(n=5 ; p<$ 0.0001 compared with $\mathrm{G} \alpha_{\mathrm{oA}+\mathrm{B}}$ antibodyinjected cells) neurons. Legend applies to

both panels. Insets demonstrate the presence of the injected antibodies in SCG neurons (injected cells indicated by arrow): left, G $\alpha_{\mathrm{OA}}+\mathrm{B}$ antibody in wild-type neuron; right, $\mathrm{G} \alpha_{\mathrm{q} / 11}$ antibody in $\mathrm{G} \alpha_{\mathrm{q}}-/-$ neuron.

that a considerable proportion of the inhibition must have been mediated by another PTX-insensitive G-protein. In $\mathrm{G} \alpha_{\mathrm{q}}$-deficient neurons, this G-protein was identifiable as $\mathrm{G} \alpha_{11}$, because the residual PTX-insensitive inhibition was virtually annulled using an antibody directed against the unique but common $\mathrm{C}$ terminus to $\mathrm{G} \alpha_{\mathrm{q}}$ and $\mathrm{G} \alpha_{11}$. Thus, in the $\mathrm{G} \alpha_{\mathrm{q}}$-deficient mice, we conclude that $\mathrm{mAChR}$-induced $\mathrm{M}$ current inhibition is maintained by $\mathrm{G} \alpha_{11}$ and by an increased contribution of the (unidentified) PTXsensitive pathway.
Thus, the present experiments reveal two clear differences from the inferences drawn from previous work on mAChRinduced $\mathrm{M}$ current inhibition in rat SCG neurons: the additional involvement of a PTX-sensitive G-protein and the greater potential involvement of $\mathrm{G} \alpha_{11}$. One possible explanation for the apparent involvement of a PTX-sensitive G-protein is that, in mouse ganglion cells, stimulation of $\mathrm{M}_{4}$ or $\mathrm{M}_{2}$ receptors might also inhibit $I_{\mathrm{K}(\mathrm{M})}$. However, this seems unlikely, because Hamilton et al. (1997) found that mAChR-induced M current inhibition was

A
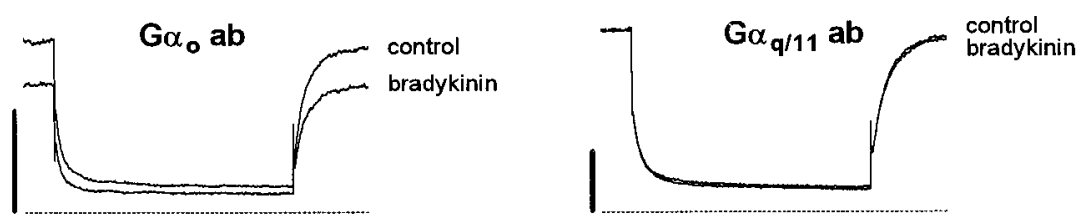

B

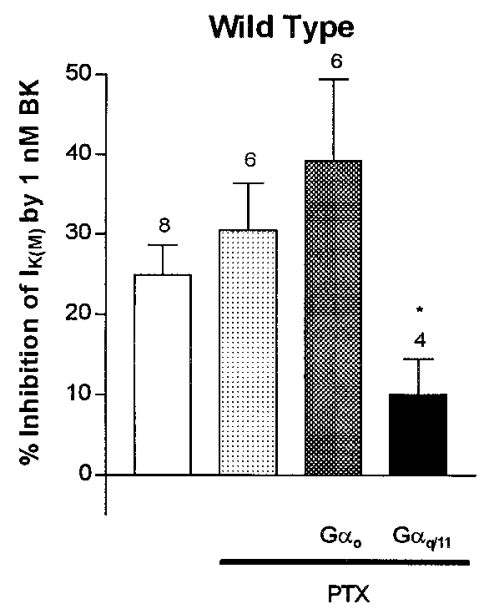

$\mathrm{G} \alpha_{q}-I-$

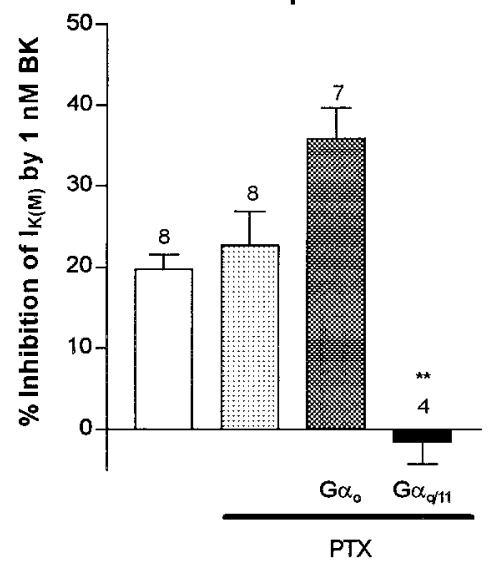

Figure 5. $\mathrm{G} \alpha_{11}$ mediates $\mathrm{BK}$ inhibition of $I_{\mathrm{K}(\mathrm{M})}$ in $\mathrm{G} \alpha_{\mathrm{q}}-/-$ neurons. $A$, Representative waveforms ( $1 \mathrm{sec}$ step from -25 to $-45 \mathrm{mV}$ ) recorded from $\mathrm{G} \alpha_{\mathrm{q}}-1-$ neurons treated with PTX and injected with $\mathrm{G} \alpha_{\mathrm{OA}+\mathrm{B}}($ left $)$ or $\mathrm{G} \alpha_{\mathrm{q} / 11}$ (right) antibody. BK (1 nM) inhibited $I_{\mathrm{K}(\mathrm{M})}$ in $\mathrm{G} \alpha_{\mathrm{OA}+\mathrm{B}^{-}}$ injected neurons but not when the $\mathrm{G} \alpha_{\mathrm{q} / 11}$ antibody was injected. The dotted lines represent 0 pA. Calibration: 250 pA. $B$, Mean \pm SEM data for inhibition by $1 \mathrm{nM} \mathrm{BK}$ in wild-type and $\mathrm{G} \alpha_{\mathrm{q}}$ $-/-$ neurons. Neither PTX treatment nor injection of the $\mathrm{G} \alpha_{\mathrm{OA}+\mathrm{B}}$ antibody significantly altered inhibition by $\mathrm{BK}$ in either wild-type or $\mathrm{G} \alpha_{\mathrm{q}}-/-$ neurons. Injection of the $\mathrm{G} \alpha_{\mathrm{q} / 11}$ antibody reduced BK inhibition in both wild-type and $\mathrm{G} \alpha_{\mathrm{q}}$ $-/-$ cells $(p<0.01$ for both compared with PTX plus $\mathrm{G} \alpha_{\mathrm{OA}+\mathrm{B}}$ antibody). 
completely annulled in mice deficient in the $\mathrm{M}_{1}$ receptor gene, implying that, as in rat neurons (Marrion et al., 1989; Bernheim et al., 1992), muscarinic inhibition of $I_{\mathrm{K}(\mathrm{M})}$ was mediated entirely by $\mathrm{M}_{1} \mathrm{mAChRs}$. Although $\mathrm{M}_{1}$ receptors are usually considered to couple exclusively to PTX-insensitive G-proteins, there have been occasional reports of at least partial PTX-sensitive responses after expression of cloned $\mathrm{M}_{1}$ receptors (Stein et al., 1988; Ashkenazy et al., 1989). Because this PTX-sensitive pathway seems unique to mouse neurons and may have limited general significance, we have not so far made any serious attempt to identify the species of G-protein involved.

Regarding the involvement of $\mathrm{G} \alpha_{11}$, in previous experiments on rat neurons, anti-G $\alpha_{\mathrm{q}}$ antisense produced a rightward shift of the dose-response curve for inhibition of $I_{\mathrm{K}(\mathrm{M})}$ by Oxo-M (Haley et al., 1998a), not dissimilar to that seen in $\mathrm{G} \alpha_{\mathrm{q}}-/-$ mouse neurons. However, although this might also suggest the involvement of another PTX-insensitive G-protein, antisense to $\mathrm{G} \alpha \alpha_{11}$ had no effect on the inhibitory effect of Oxo-M in rat neurons. Hence, it was concluded that the limited effect of $\mathrm{G} \alpha_{\mathrm{q}}$ antisense probably resulted from incomplete protein suppression rather than to the additional effect of another G-protein. Nevertheless, it is necessary to point out that, although $\mathrm{G} \alpha_{11}$ can sustain $\mathrm{mAChR}$ induced $\mathrm{M}$ current inhibition in $\mathrm{G} \alpha_{\mathrm{q}}$-deficient mice, we have no direct evidence from the present experiments that $\mathrm{G} \alpha_{11}$ mediates any part of the response of normal (wild-type) mouse neurons to Oxo-M; the reduced inhibition seen in the presence of the $\mathrm{G} \alpha_{\mathrm{q} / 11}$ antibody could equally well have been attributable to antagonism of either endogenous $\mathrm{G} \alpha_{\mathrm{q}}$ or $\mathrm{G} \alpha_{11}$. The large contribution of $\mathrm{G} \alpha_{11}$ in $\mathrm{G} \alpha_{\mathrm{q}}-/-$ neurons might then be an adaptive change, perhaps resulting from a redistribution of G-proteins in the plasma membrane, because there is no evidence for compensatory overexpression of $\mathrm{G} \alpha_{11}$ in the nervous system of these mice (Offermanns et al., 1997b). Hence, the present observations do not necessarily negate our previous conclusion that mAChRinduced $\mathrm{M}$ current inhibition in normal rat neurons results primarily from activation of $\mathrm{G} \alpha_{\mathrm{q}}$. In this context, it should be noted that previous observations have revealed differences between the coupling of muscarinic receptors to ion channels in mouse and rat SCG neurons. Thus, in the mouse, inhibition of $I_{\mathrm{Ca}}$ is mediated by $\mathrm{M}_{2}$ receptors (Shapiro et al., 1999) whereas the corresponding response in rat SCG neurons is mediated by $\mathrm{M}_{4}$ receptors (Bernheim et al., 1992); indeed, although rat neurons possess functional $\mathrm{M}_{2}$ receptors capable of activating PTX-sensitive G-proteins, they appear not to inhibit $I_{\mathrm{Ca}}$ (Fernandez-Fernandez et al., 1999).

The effects of BK on $I_{\mathrm{K}(\mathrm{M})}$ in mouse ganglion cells seem to match those on rat SCG neurons much more closely. Thus, $1 \mathrm{nM}$ BK produced the same amount of inhibition in both, and neither showed any sensitivity to PTX (unlike muscarinic inhibition). Previous experiments on rat neurons using G-protein antibodies (Jones et al., 1995) strongly suggested that inhibition was mediated by either $\mathrm{G} \alpha_{\mathrm{q}}$ or $\mathrm{G} \alpha_{11}$ (or both) but could not identify which. Because in the present experiments inhibition was unchanged in neurons from $\mathrm{G} \alpha_{\mathrm{q}}-/-$ mice and then annulled by anti-G $\alpha_{\mathrm{q} / 11}$ antibody, we infer that inhibition in normal SCG neurons is probably mediated exclusively by $\mathrm{G} \alpha_{11}$ (although with the caveat regarding possible adaptive responses after $\mathrm{G} \alpha_{\mathrm{q}}$ deletion expressed above). Lack of any involvement of $\mathrm{G} \alpha_{\mathrm{q}}$ would accord with the fact that, unlike $\mathrm{mAChR}$ stimulation, BK did not inhibit $I_{\mathrm{Ca}}$ in the mouse ganglion cells.

The reason for this apparent selectivity of BK receptors for $\mathrm{G} \alpha_{11}$ in mouse neurons (and possibly in rat neurons) is unclear.
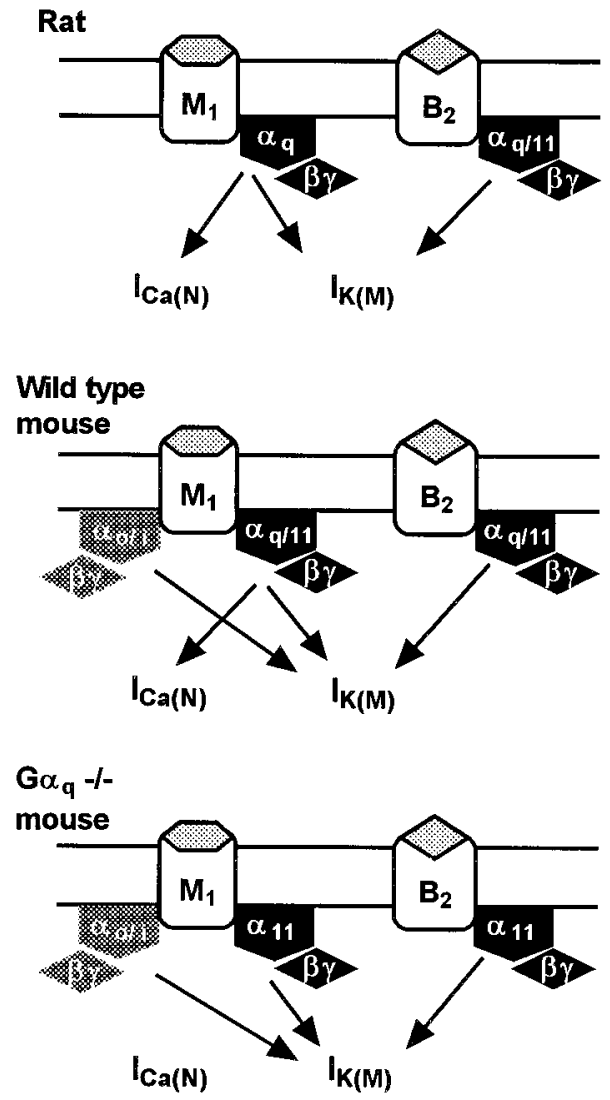

Figure 6. Diagram to summarize projected G-protein involvement for $\mathrm{M}_{1} \mathrm{mAChR}$ - and $\mathrm{B}_{2} \mathrm{BK}$ receptor-induced inhibition of $I_{\mathrm{Ca}}$ and $I_{\mathrm{K}(\mathrm{M})}$ channels in rat SCG neurons and in wild-type and $\mathrm{G} \alpha_{\mathrm{q}}$-deficient mouse SCG neurons.

Although it is usually assumed that BK can activate $\mathrm{G} \alpha$, we are unaware of any experiments that unequivocally distinguish effects mediated by $\mathrm{G} \alpha_{\mathrm{q}}$ from those that might equally be mediated by $\mathrm{G} \alpha_{11}$. On the contrary, Ricupero et al. (1997) have reported that BK-induced stimulation of phospholipase $C$ was enhanced, rather than inhibited, in mouse embryonic stem cells lacking $\mathrm{G} \alpha_{\mathrm{q}}$, whereas Wilk-Blaszczak et al. (1994b) identified $\mathrm{G}_{13}$ as the $\mathrm{G}$-protein responsible for the PTX-insensitive component of $I_{\mathrm{Ca}}$ inhibition in neuroblastoma hybrid cells. [In previous experiments, these authors (Wilk-Blaszczak et al., 1994a) had identified $\mathrm{G}_{\mathrm{q} / 11}$ as mediating the phospholipase $\mathrm{C}$-driven activation of $I_{\mathrm{K}(\mathrm{Ca})}$ in these cells but, because this was from anti- $\mathrm{G}_{\mathrm{q} / 11}$ antibody infusion, it could have resulted from activation of $G_{q}, G_{11}$, or both.]

In conclusion, the present results point to a surprising degree of divergence at the G-protein level in the coupling of $\mathrm{M}_{1} \mathrm{mAChR}$ and $\mathrm{B}_{2} \mathrm{BK}$ receptors to $\mathrm{Ca}^{2+}$ and $\mathrm{K}_{\mathrm{M}}{ }^{+}$channels in SCG neurons (Fig. 6). Thus, in the mouse ganglion, $M_{1} m A C h R$ inhibition of $I_{\mathrm{Ca}}$ appears to be mediated exclusively (or almost so) by $\mathrm{G} \alpha$, whereas inhibition of $I_{\mathrm{K}(\mathrm{M})}$ also involves both $\mathrm{G} \alpha_{11}$ and an additional unidentified PTX-sensitive G-protein. BK does not inhibit $I_{\mathrm{Ca}}$, and its inhibition of $I_{\mathrm{K}(\mathrm{M})}$ is probably mediated exclusively by $\mathrm{G} \alpha_{11}$. This divergence at the level of G-protein coupling may go some way toward explaining the apparent divergence in the subsequent steps to $M$ current inhibition after activation of $M_{1}$ mAChRs or $B_{2} B K$ receptors, namely, that BK-induced inhibition appears to involve activation of a phospholipase $C$, whereas $M_{1}$ muscarinic inhibition does not (Cruzblanca et al., 1998; Haley et 
al., 1998b). The difference in G-protein coupling from $\mathbf{M}_{1}$ mAChRs to $\mathrm{Ca}^{2+}$ channels and $\mathrm{K}_{\mathrm{M}}{ }^{+}$channels might equally imply that, contrary to previous inferences (Hille, 1994), the modulation of these two channels may also involve different transduction pathways.

\section{REFERENCES}

Ashkenazy A, Peralta EG, Winslow JW, Ramachandran J, Capon D (1989) Functionally distinct $G$ proteins selectively couple different receptors to PI hydrolysis in the same cell. Cell 56:487-493.

Bernheim L, Mathie A, Hille B (1992) Characterization of muscarinic receptor subtypes inhibiting $\mathrm{Ca}^{2+}$ current and $\mathrm{M}$ current in rat sympathetic neurons. Proc Natl Acad Sci USA 89:9544-9548.

Brown DA (1988) M currents. In: Ion channels, Vol 1 (Narahashi T, ed), pp 55-99. New York: Plenum.

Brown DA (1999) M-Current: from discovery to single channel currents. In: Slow synaptic responses and modulation (Kuba K, ed), pp 15-26. Berlin: Springer.

Brown DA, Marrion NV, Smart TG (1989) On the transduction mechanism for muscarine-induced inhibition of M-current in rat sympathetic neurons. J Physiol (Lond) 413:469-488.

Caulfield MP, Jones S, Vallis Y, Buckley NJ, Kim G-D, Milligan G, Brown DA (1994) Muscarinic M-current inhibition via $G_{\alpha q / 11}$ and $\alpha$-adrenoceptor inhibition of $\mathrm{Ca}^{2+}$ current via $\mathrm{G}_{\alpha \mathrm{o}}$ in rat sympathetic neurones. J Physiol (Lond) 477:415-422.

Cruzblanca H, Koh D-S, Hille B (1998) Bradykinin inhibits M current via phospholipase $\mathrm{C}$ and $\mathrm{Ca}^{2+}$ release from $\mathrm{IP}_{3}$-sensitive $\mathrm{Ca}^{2+}$ stores in rat sympathetic neurons. Proc Natl Acad Sci USA 95:7151-7156.

Davies PJ, Ireland DR, McLachlan EM (1996) Sources of $\mathrm{Ca}^{2+}$ for different $\mathrm{Ca}^{2+}$-activated $\mathrm{K}^{+}$conductances in neurones of the rat superior cervical ganglion. J Physiol (Lond) 495:353-366.

Delmas P, Abogadie FC, Dayrell M, Haley JE, Milligan G, Caulfield MP, Brown DA, Buckley NJ (1998a) G-proteins and G-protein subunits mediating cholinergic inhibition of N-type calcium currents in sympathetic neurons. Eur J Neurosci 10:1654-1666.

Delmas P, Brown DA, Dayrell M, Abogadie FC, Caulfield MP, Buckley NJ (1998b) On the role of endogenous G-protein $\beta \gamma$ subunits in $\mathrm{N}$-type $\mathrm{Ca}^{2+}$ current inhibition by neurotransmitters in rat sympathetic neurones. J Physiol (Lond) 506:319-329.

Delmas P, Abogadie FC, Milligan G, Buckley NJ, Brown DA (1999) $\beta \gamma$ dimers derived from $G_{o}$ and $G_{i}$ proteins contribute different components of adrenergic inhibition of $\mathrm{Ca}^{2+}$ channels in rat sympathetic neurones. J Physiol (Lond) 518:23-36.

Fernandez-Fernandez JM, Wanaverbecq N, Halley P, Caulfield MP, Brown DA (1999) A role for $\mathbf{M}_{2}$ receptors in the muscarinic activation of $\mathrm{G}$ protein-gated $\mathrm{K}^{+}$(GIRK) channels expressed in isolated rat sympathetic neurones. J Physiol (Lond) 515:631-637.

Gudermann T, Kalkbrenner F, Schultz G (1996) Diversity and selectivity of receptor-G protein interaction. Annu Rev Pharmacol Toxicol $36: 429-459$

Haley JE, Abogadie FC, Delmas P, Dayrell M, Vallis Y, Milligan G, Caulfield MP, Brown DA, Buckley NJ (1998a) The $\alpha$ subunit of $\mathrm{G}_{\mathrm{q}}$ contributes to muscarinic inhibition of the M-type potassium current in sympathetic neurons. J Neurosci 18:4521-4531.

Haley JE, Abogadie FC, Dayrell M, Buckley NJ, Brown DA (1998b) Antisense against phospholipase $\mathrm{C}$ - $\beta 4$ reduces inhibition of M-current $\left(\mathrm{I}_{\mathrm{K}(\mathrm{M})}\right)$ by bradykinin, but not by the muscarinic agonist oxotremorine-M (Oxo-M) in rat sympathetic ganglion (SCG) neurones. J Physiol (Lond) 515P:131P.

Haley JE, Delmas P, Offermanns S, Abogadie FC, Buckley NJ, Simon MI, Brown DA (1998c) Muscarinic M1 inhibition of calcium current, but not M-type potassium current, is reduced in $\mathrm{G} \alpha \mathrm{q}$ knockout mice. Naunyn Schmiedebergs Arch Phamacol 358:R646.
Hamilton SE, Loose MD, Qi M, Levey AI, Hille B, McKnight GS, Idzerda RL, Nathanson NM (1997) Disruption of the m1 receptor gene ablates muscarinic receptor-dependent $\mathrm{M}$ current regulation and seizure activity in mice. Proc Natl Acad Sci USA 94:13311-13316.

Hille B (1994) Modulation of ion-channel function by G-protein-coupled receptors. Trends Neurosci 17:531-536.

Horn R, Marty A (1988) Muscarinic activation of ionic currents measured by a new whole-cell recording method. J Gen Physiol 92:145-159.

Jones S, Brown DA, Milligan G, Willer E, Buckley NJ, Caulfield MP (1995) Bradykinin excites rat sympathetic neurons by inhibition of $\mathrm{M}$ current through a mechanism involving $B_{2}$ receptors and $G_{\alpha q / 11}$. Neuron 14:399-405.

Jones SW, Adams PR (1987) The M-current and other potassium currents of vertebrate neurons. In: Neuromodulation (Kaczmarek LK, Levitan IB, eds), pp 159-186. New York: Oxford UP.

Marrion NV, Smart TG, Marsh SJ, Brown DA (1989) Muscarinic suppression of the M-current in the rat sympathetic ganglion is mediated by receptors of the $\mathrm{M}_{1}$-subtype. Br J Pharmacol 98:557-573.

Milligan G, Mullaney I, McCallum JF (1993) Distribution and relative levels of expression of the phosphoinositidase-C-linked G-proteins $\mathrm{G}_{\mathrm{q}} \alpha$ and $\mathrm{G}_{11} \alpha$ : absence of $\mathrm{G}_{11} \alpha$ in human platelets and haemopoietically derived cell lines. Biochem Biophys Acta 1179:208-212.

Offermanns S, Wieland T, Homann D, Sandmann J, Bombien E, Spicher K, Schultz G, Jakobs KH (1994) Transfected muscarinic actelycholine receptors selectively couple to $\mathrm{G}_{\mathrm{i}}$-type $\mathrm{G}$ proteins and $\mathrm{G}_{\mathrm{q} / 11}$. Mol Pharmacol 45:890-898.

Offermanns S, Hashimoto K, Watanabe M, Sun W, Kurihara H, Thompson RF, Inoue Y, Kano M, Simon MI (1997a) Impaired motor coordination and persistent multiple climbing fiber innervation of cerebellar Purkinje cells in mice lacking G $\alpha \mathrm{q}$. Proc Natl Acad Sci USA 94:14089-14094.

Offermanns S, Toombs CF, Hu Y-H, Simon MI (1997b) Defective platelet activation in $\mathrm{G} \alpha_{\mathrm{q}}$-deficient mice. Nature 389:183-186.

Rae J, Cooper K, Gates P, Watsky M (1991) Low access resistance perforated patch recordings using amphotericin B. J Neurosci Methods 37:15-26.

Ricupero DA, Polgar P, Taylor L, Sowell MO, Gao Y, Bradwin G, Mortensen RM (1997) Enhanced bradykinin-stimulated phospholipase $\mathrm{C}$ activity in murine embryonic stem cells lacking the G-protein $\alpha_{\mathrm{q}}$ subunit. Biochem J 327:803-809.

Sah P (1996) $\mathrm{Ca}^{2+}$-activated $\mathrm{K}^{+}$currents in neurones: types, physiological roles and modulation. Trends Neurosci 19:150-154.

Schofield GG (1991) Norepinephrine inhibits a $\mathrm{Ca}^{2+}$ current in rat sympathetic neurons via a G-protein. Eur J Pharmacol 207:195-207.

Shapiro MS, Loose MD, Hamilton SE, Nathanson NM, Gomeza J, Wess J, Hille B (1999) Assignement of muscarinic receptor subtypes mediating G-protein modulation of $\mathrm{Ca}^{2+}$ channels by using knockout mice. Proc Natl Acad Sci USA 96:10899-10904.

Stein R, Pinkas-Kramarski R, Sokolovsky M (1988) Cloned M1 muscarinic receptors mediate both adenylate cyclase inhibition and phosphoinositide turnover. EMBO J 7:3031-3035.

Wang H-S, McKinnon D (1995) Potassium currents in rat prevertebral and paravertebral sympathetic neurones: control of firing properties. J Physiol (Lond) 485:319-335.

Wilk-Blaszczak MA, Gutowski S, Sternweis PC, Belardetti F (1994a) Bradykinin modulates potassium and calcium currents in neuroblastoma hybrid cells via different pertussis toxin-insensitive pathways. Neuron 12:109-116.

Wilk-Blaszczak MA, Singer WD, Gutowski S, Sternweis PC, Belardetti F (1994b) The $G$ protein $G_{13}$ mediates inhibition of voltage-dependent calcium current by bradykinin. Neuron 13:1215-1224.

Zhu Y, Ikeda SR (1994) Modulation of $\mathrm{Ca}^{2+}$-channel currents by protein kinase $\mathrm{C}$ in adult rat sympathetic neurons. J Neurophysiol 72:15491560 . 